JCEBT, 5 (2) September 2021 ISSN 2549-6379 (Print) ISSN 2549-6387 (Online)
JCEBT
(Journal of Civil Engineering, Building and Transportation)
Available online http://ojs.uma.ac.id/index.php/jcebt

\title{
Pengaruh Serbuk Abu Cangkang Kerang Sebagai Bahan Pengganti Filler Pada Campuran Aspal
}

\section{Effect of Shell Ash Powder as a Substitute for Filler in Asphalt Mixture}

\author{
Kartika Indah Sari \\ Program Studi Teknik Sipil, Fakultas Teknik Dan Komputer \\ Univesitas Harapan, Medan, Indonesia \\ *Corresponding Email: mutiyalubis@gmail.com
}

\begin{abstract}
Abstrak
Aspal merupakan bahan utama dalam perkerasan jalan. Spesifikasi campuran Asphalt Concrete Wearing Course $(A C-W C)$ mengacu pada Spesifikasi Kementrian Pekerjaan Umum Direktorat Jendral Bina Marga 2010 revisi 1 (BM 2010). Pengujian Marshall test yang meliputi : stabilitas, flow, Marshall Quotient, Voids In Mixture (VIM), Voids in Mineral Agregat (VMA), dan Voids Filled by Asphalt (VFA). Pada campuran AC-WC yang menggunakan agregat halus yaitu filler cangkang kerang . Cangkang kerang yang digunakan berasal dari daerah Tanjung Balai. Dari hasil penelitian pengaruh penggantian sebagian filler cangkang kerang sebesar $15 \%$ dan 25\% yang menunjukan perubahan nilai stabiltas untuk cmpuran 15\% sebesar $1192 \mathrm{~kg}$ dan $25 \%$ sebsar 1245 kg sedangkan Spesifikasi Kementrian Pekerjaan Umum Direktorat Jendral Bina Marga 2010 revisi 1 sebesar $800 \mathrm{~kg}$ telah memenuhi syarat spesifikasi.
\end{abstract}

Kata Kunci : Filler Cangkang Kerang, Agregat Halus, Cangkang kerang, Beton aspal lapis antara

\section{Abstract}

Asphalt is the main ingredient in road pavement. The specification of the Asphalt Concrete Wearing Course (ACWC) mixture refers to the Specifications of the Ministry of Public Works, Directorate General of Highways 2010 revision 1 (BM 2010). Marshall test includes: stability, flow, Marshall Quotient, Voids In Mixture (VIM), Voids in Mineral Aggregate (VMA), and Voids Filled by Asphalt (VFA). In the AC-WC mixture that uses fine aggregate, namely clam shell filler. The shells used are from the Tanjung Balai area. From the results of the study, the effect of partial replacement of oyster shell filler was $15 \%$ and $25 \%$ which showed a change in the stability value for $15 \%$ mixture of $1192 \mathrm{~kg}$ and 25\% of $1245 \mathrm{~kg}$ while the Specifications of the Ministry of Public Works of the Directorate General of Highways 2010 revision 1 of $800 \mathrm{~kg}$ had met specification requirements.

Keywords : Shell Shell Filler, Fine Aggregate, Shell Shell, Intermediate Asphalt Concrete

How to Cite: Sari, K., I. (2021). Pengaruh Serbuk Abu Cangkang Kerang Sebagai Bahan Pengganti Filler Pada Campuran Aspal. JCEBT (Journal of Civil Engineering, Building and Transportation). 5 (2): 132 - 142 


\section{PENDAHULUAN}

Aspal merupakan bahan utama dalam perkerasan jalan. Aspal memiliki beberapa jenis, yaitu aspal alam, aspal keras, aspal cair, dan aspal modifikasi. Aspal memiliki sifat viskoelastis yaitu sifat untuk mencair pada suhu tinggi dan memadat pada suhu rendah. Sifat yang dimiliki aspal tersebut merupakan hal utama yang menjadikan aspal sebagai bahan utama dalam perkerasan jalan karena dapat mengikat bahan-bahan pencampur perkerasan jalan. Perkerasan jalan yang baik adalah perkerasan jalan yang mampu menahan beban lalu lintas. Perkerasan jalan yang digunakan di Indonesia terdiri dari beberapa jenis. Perkerasan jalan yang paling banyak digunakan di Indonesia adalah lapisan aspal beton atau Laston (AC/Asphalt Concrete). Lapisan aspal beton banyak digunakan karena jenis perkerasan ini memiliki nilai stabilitas dan fleksibilitas yang baik.

Agregat kasar, agregat halus, agregat sedang, bahan pengisi (filler), dan aspal merupakan bahan-bahan pencampur lapisan aspal beton. Bahan-bahan pencampur ini harus memiliki karakteristik yang sesuai dengan persyaratan yang sudah ada agar perkerasan jalan aspal beton memiliki stabilitas dan fleksibilitas yang baik.
Bahan pengisi (filler) dalam campuran aspal beton adalah bahan yang lolos saringan No.200 (0,075 mm).

Bahan pengisi bertujuan untuk meningkatkan kekentalan bahan bitumen dan untuk mengurangi sifat rentan terhadap temperatur. Keuntungan lain dengan adanya bahan pengisi adalah karena banyak terserap dalam bahan bitumen maka akan menaikkan volumenya. Selain itu bahan pengisi (filler) dapat mengurangi volume pori-pori atau rongga sehingga dapat meningkatkan kepadatan dan dapat menurunkan permeabilitas campuran aspal.

Kadar bahan pengisi (filler) pada campuran beraspal sangat mempengaruhi sifat campuran beraspal tersebut, jika terlalu banyak kadar bahan pengisi maka campuran tersebut akan menjadi kaku dan mudah retak. Namun sebaliknya apabila kadar bahan pengisi pada campuran terlalu sedikit maka akan membuat campuran tersebut menjadi sangat lentur dan mudah terdeformasi oleh beban lalu lintas sehingga jalan tersebut akan bergelombang. Pada penelitian ini kadar bahan pengisi (filler) sebesar 4\% dari berat total campuran. Jenis bahan pengisi yang digunakan pada penelitian ini adalah semen portland tipe I. Penelitian ini mengacu pada spesifikasi teknis jalan Bina Marga tahun 2010 revisi I. 


\section{METODELOGI PENELITIAN}

Pelaksanaan penelitian dilakukan di Laboratorium Program Studi Teknik Sipil Fakultas Teknik Universitas Islam Sumatera Utara. Peneitian yang akan diuji pada campuran.

Asphalt Concrete Binder Course (AC$B C$ ) adalah Marshall test dengan variasi penggantian sebagian filler sebesar $15 \%$ dan 25\% dimana bahan utama filler berupa Cangkag Kerang Darah. Semua bahan yang digunakan pada penelitian ini mengacu pada spesifikasi umum yang dikeluarkan oleh Direktorat Jenderal Bina Marga tahun 2010 Revisi I.

Bahan yang digunakan dalam penelitian ini meliputi :

1. Agregat kasar (split)

2. Agregat halus

3. Filler

Rancangan campuran dalam penelitian ini menggunakan metode Marshall. Hal ini dikarenakan metode Marshall lebih mudah diaplikasikan. Langkah-langkah rancangan untuk menggunakan metode ini adalah sebagai berikut :

1. Mempelajari spesifikasi gradasi agregat campuran yang diinginkan dari Spesifikasi Umum.

2. Merancang proporsi agregat, proporsi ini ditentukan secara analitis dimana proporsi agregat tersebut dipilih dari gradasi yang sesuai BM 2010 Tabel 2.9.

3. Mendapatkan kadar aspal total dalam campuran menggunakan rumus 2.1.

4. Menghitung kebutuhan agregat kasar, agregat halus dan filler sesuai dengan komposisi yang didapat. Berat total agregat 1200 gram untuk satu benda uji (tanpa apal). Berat aspal didapat dari persen kadar aspal x 1200 gram (berat total agregat)

\section{ANALISIS DATA DAN PEMBAHASAN}

Pengujian kualitas material dalam campuran aspal panas ini terdiri dari material agregat dan aspal. Sedangkan material agregat itu sendiri terdiri dari agregat kasar, agregat halus dan filler. Kualitas material dapat diketahui dengan dua macam pemeriksaan, yaitu dengan cara visual dan cara percobaan sehingga diperoleh data laboratorium Universitas Islam Sumatera Utara Fakultas Tekhnik. Pemeriksaan visual berupa pemeriksaan terhadap bentuk butiran dan tekstur permukaan agregat kasar. Hasil pemeriksaan menunjukkan bahwa agregat yang digunakan memiliki tekstur permukaan yang kasar (rough) dan mempunyai bentuk yang bervariasi.

Gradasi yang digunakan adalah Revisi Standar Nasional Indonesia (SNI) 
03- 1737-1989. Hasil analisis saringan CA,MA,FA dan NS dapat dilihat pada lampiran B.1 - B.4. Untuk gradasi rencana campuran dapat dilihat pada tabel $4.1 \mathrm{di}$ bawah ini : Tabel 4.1. Gradasi Rencana Campuran AC Spec IV SNI 03-1737-1989.

Tabel 4.1. Hasil Pengujian Agregat Kasar

\begin{tabular}{|c|l|c|c|c|c|}
\hline No & \multicolumn{1}{|c|}{ Karakteristik } & Standar Pengujian & Hasil & Persyaratan & $\begin{array}{c}\text { Keteranga } \\
\text { n }\end{array}$ \\
\hline 1. & Berat jenis dan penyerapan air & AASHTO T-85-81 & $\begin{array}{c}2,567 \mathrm{gr} / \mathrm{c} \\
\mathrm{c}\end{array}$ & - & - \\
\hline 2. & Berat Jenis SSD & AASHTO T-85-81 & $\begin{array}{c}2,593 \mathrm{gr} / \mathrm{c} \\
\mathrm{c}\end{array}$ & - & - \\
\hline 3. & Berat Jenis Apparent & AASHTO T-85-81 & $\begin{array}{c}2,637 \mathrm{gr} / \mathrm{c} \\
\mathrm{c}\end{array}$ & - & - \\
\hline 4. & Penyerapan Air & SNI 1969-1989- F & $1,031 \%$ & maks. 3\% & Memenuhi \\
\hline 5. & $\begin{array}{l}\text { Abrasi dengan mesin Los } \\
\text { Angeles }\end{array}$ & SNI 03-2417-1991 & $23,7 \%$ & maks. 40\% & Memenuhi \\
\hline 6. & $\begin{array}{l}\text { Kelekatan agregat terhadap } \\
\text { aspal }\end{array}$ & SNI 03-2439-1991 & $98,0 \%$ & min. 95\% & Memenuhi \\
\hline 7. & Indeks kepipihan & ASTM D-4791 & $15,9 \%$ & maks. 25\% & Memenuhi \\
\hline 8. & Indeks kelonjongan & ASTM D-4791 & $8,4 \%$ & maks. 10\% & Memenuhi \\
\hline 9. & Material lolos saringan no.200 & SNI 03-4142-1996 & $0,5 \%$ & maks. 1\% & Memenuhi \\
\hline
\end{tabular}

Sumber : Syarat Pelaksanaan Lapis Aspal Beton untuk Jalan Raya

Tabel 4.2 Hasil Pengujian Agregat Halus

\begin{tabular}{|l|l|c|c|c|c|}
\hline NO & Karakteristik & Standar Pengujian & Hasil & Persyaratan & Keterangan \\
\hline 1 & Berat jenis dan penyerapan & AASHTO T-85 - 81 & $2,576 \mathrm{gr} / \mathrm{c}$ & - & - \\
\hline 2 & Berat Jenis SSD & AASHTO T-85 - 81 & $2,600 \mathrm{gr} / \mathrm{c}$ & - & - \\
\hline 3 & Berat Jenis Apparent & AASHTO T-85 - 81 & $\begin{array}{c}2,641 \mathrm{gr} / \mathrm{c} \\
\mathrm{c}\end{array}$ & - & - \\
\hline 4 & Penyerapan Air & SNI 1969-1989- F & $0,960 \%$ & maks. 3\% & Memenuhi \\
\hline 5 & Nilai setara pasir & SNI 03-4428-1997 & $74,51 \%$ & min. 50\% & Memenuhi \\
\hline 6 & Material lolos saringan & SNI 03-4428-1997 & $5,0 \%$ & maks. 8\% & Memenuhi \\
\hline
\end{tabular}

Sumber : Kementrian Pekerjaan Umum Dirjen Bina Marga, 2010 Revisi I Divisi 6

Tabel 4.3. Hasil Pengujian Filler

\begin{tabular}{|c|c|c|c|c|}
\hline Jenis Filler & Karakteristik & Standar Pengujian & Hasil & Spesifikasi \\
\hline \multirow{2}{*}{ I.Abu Batu } & Lolos saringan no.200 & SNI M-02-1994-03 & $88,8 \%$ & min. $70 \%$ \\
\cline { 2 - 5 } & Berat Jenis & AASHTO T-85 - 81 & $2,603 \mathrm{gr} / \mathrm{cc}$ & \\
\hline
\end{tabular}

Sumber : Hasil Laboratorium

Tabel 4.4. Hasil pemeriksaan aspal

\begin{tabular}{|l|l|c|c|c|}
\hline \multirow{2}{*}{ No } & \multicolumn{1}{|c|}{ Jenis Pemeriksaan } & \multicolumn{2}{c|}{ Syarat } & \multirow{2}{*}{ Hasil } \\
\cline { 3 - 4 } & & Min & Max & \\
\hline 1 & Penetrasi, 10gr, 25 oㄷ, 5 detik (mm) & 60 & 79 & 70,1 \\
\hline 2 & Titik Lembek ( oC) & 48 & 58 & 48,33 \\
\hline 3 & Titik Nyala ( oC) & 200 & - & 350 \\
\hline 4 & Titik Bakar ( oC) & 200 & - & 370 \\
\hline 5 & Daktilitas, 25 으, 5 cm/menit (cm) & 100 & - & $>150$ \\
\hline 6 & Spesific Grafity (gr/cc) & 1 & - & 1,03 \\
\hline
\end{tabular}

Sumber : Kementrian Pekerjaan Umum Dirjen Bina Marga, 2010 Revisi I Divisi 6 
Sari, K., I. (2021). Pengaruh Serbuk Abu Cangkang Kerang Sebagai Bahan Pengganti Filler Pada Campuran Aspal.

Tabel 4.5. Gradasi rencana campuran AC-WC spek IV SNI 03-1737-1989

\begin{tabular}{|c|c|c|}
\hline Ukuran Saringan & Spesifikasi (\% Lolos) & Gradasi Ideal (\% Lolos) \\
\hline $3 / 4$ & 100 & 100 \\
\hline $1 / 2$ & $80-100$ & 90 \\
\hline $3 / 8$ & $70-90$ & 80 \\
\hline$\# 4$ & $50-70$ & 60 \\
\hline$\# 8$ & $35-50$ & 42,5 \\
\hline$\# 30$ & $18-29$ & 23,5 \\
\hline$\# 50$ & $13-23$ & 18 \\
\hline$\# 100$ & $8-16$ & 12 \\
\hline 200 & $4-10$ & 7 \\
\hline
\end{tabular}

Sumber: SNI 03-1737-1989

Tabel. 4.6 Gradasi Rencana Campuran

\begin{tabular}{|c|c|c|c|c|c|c|c|c|c|c|}
\hline \multicolumn{11}{|c|}{ Gradasi Rencana Campuran Murni } \\
\hline \multicolumn{11}{|c|}{ Coarse Agg 3/4" } \\
\hline \multirow{2}{*}{\multicolumn{2}{|c|}{ Sieve Size }} & \multicolumn{4}{|c|}{ Sample 1} & \multicolumn{4}{|c|}{ Sample 2} & \multirow{3}{*}{$\begin{array}{c}\text { Averag } \\
\text { e } \\
\text { Passin } \\
\text { g } \\
(\%)\end{array}$} \\
\hline & & \multirow{2}{*}{$\begin{array}{l}\text { Individ } \\
\text { ual Wt } \\
\text { Retain } \\
\text { ed (Gr) }\end{array}$} & \multicolumn{3}{|c|}{ Weight Cumulative } & \multirow{2}{*}{$\begin{array}{l}\text { Individ } \\
\text { ual Wt } \\
\text { Retain } \\
\text { ed (Gr) }\end{array}$} & \multicolumn{3}{|c|}{ Weight Cumulative } & \\
\hline Inch & $\mathrm{mm}$ & & $\begin{array}{c}\text { Retain } \\
\text { ed } \\
\text { (Gr) }\end{array}$ & $\begin{array}{l}\text { Retain } \\
\text { d (\%) }\end{array}$ & $\begin{array}{c}\text { Passin } \\
\text { g (\%) }\end{array}$ & & $\begin{array}{l}\text { Retai } \\
\text { ned } \\
(\mathrm{Gr})\end{array}$ & $\begin{array}{c}\text { Retain } \\
\text { d (\%) }\end{array}$ & $\begin{array}{c}\text { Passin } \\
\mathrm{g}(\%)\end{array}$ & \\
\hline $3 / 4$ & 19,1 & & & & 100,00 & & & & 100,00 & 100,00 \\
\hline $1 / 2$ & 12,7 & 1591 & 1591 & 21,44 & 78,56 & & 1451 & 20,77 & 79,23 & 78,90 \\
\hline $3 / 8$ & 9,5 & 2680 & 4271 & 57,57 & 42,43 & & 3837 & 54,93 & 45,07 & 43,75 \\
\hline No. 4 & 4,76 & 2430 & 6702 & 90,33 & 9,67 & & 6303 & 90,23 & 9,77 & 9,72 \\
\hline No. 8 & 2,88 & 619 & 7321 & 98,68 & 1,32 & & 6883 & 98,54 & 1,46 & 1,39 \\
\hline No. 16 & 1,19 & 21 & 7342 & 98,96 & 1,04 & & 6909 & 98,91 & 1,09 & 1,07 \\
\hline No. 30 & 0,595 & 23 & 7365 & 99,27 & 0,73 & & 6925 & 99,14 & 0,86 & 0,80 \\
\hline No. 50 & 0,297 & & & & & & & & & \\
\hline \multicolumn{2}{|c|}{ Total Weight } & 7419 & & & & 6985 & & & & \\
\hline \multicolumn{11}{|c|}{ Medium Agg 1/2" } \\
\hline \multirow{2}{*}{\multicolumn{2}{|c|}{ Sieve Size }} & \multicolumn{4}{|c|}{ Sample 1} & \multicolumn{4}{|c|}{ Sample 2} & $\begin{array}{c}\text { Averag } \\
\mathrm{e}\end{array}$ \\
\hline & & $\begin{array}{c}\text { Individ } \\
\text { ual Wt }\end{array}$ & \multicolumn{3}{|c|}{ Weight Cumulative } & $\begin{array}{l}\text { Individ } \\
\text { ual Wt }\end{array}$ & \multicolumn{3}{|c|}{ Weight Cumulative } & $\begin{array}{c}\text { Passin } \\
\mathrm{g}\end{array}$ \\
\hline Inch & $\mathrm{mm}$ & $\begin{array}{l}\text { Retain } \\
\text { ed (Gr) }\end{array}$ & $\begin{array}{c}\text { Retain } \\
\text { ed } \\
\text { (Gr) }\end{array}$ & $\begin{array}{l}\text { Retain } \\
\text { d (\%) }\end{array}$ & $\begin{array}{c}\text { Passin } \\
\mathrm{g}(\%)\end{array}$ & $\begin{array}{l}\text { Retain } \\
\text { ed (Gr) }\end{array}$ & $\begin{array}{l}\text { Retai } \\
\text { ned } \\
(\mathrm{Gr}) \\
\end{array}$ & $\begin{array}{c}\text { Retain } \\
\text { d (\%) }\end{array}$ & $\begin{array}{c}\text { Passin } \\
\mathrm{g}(\%)\end{array}$ & $(\%)$ \\
\hline $3 / 4$ & 19 & & & & & & & & & \\
\hline $1 / 2$ & 12,7 & & & & 100,00 & & & & 100,00 & 100,00 \\
\hline $3 / 8$ & 9,5 & & 238 & 5,65 & 94,35 & & 112 & 2,78 & 97,22 & 95,79 \\
\hline No. 4 & 4,76 & & 2234 & 53,00 & 47,00 & & 2219 & 55,00 & 45,00 & 46,00 \\
\hline No. 8 & 2,88 & & 3459 & 82,06 & 17,94 & & 3276 & 81,20 & 18,80 & 18,37 \\
\hline No. 16 & 1,19 & & 3901 & 92,54 & 7,46 & & 3718 & 92,14 & 7,86 & 7,66 \\
\hline No. 30 & 0,595 & & 4015 & 95,25 & 4,75 & & 3830 & 94,91 & 5,09 & 4,92 \\
\hline No. 50 & 0,297 & & 4100 & 97,28 & 2,72 & & 3919 & 97,12 & 2,88 & 2,80 \\
\hline No. 100 & 0,150 & & 4141 & 98,24 & 1,76 & & 3953 & 97,98 & 2,02 & 1,89 \\
\hline No. 200 & 0,074 & & 4175 & 99,06 & 0,94 & & 3989 & 98,86 & 1,14 & 1,04 \\
\hline \multicolumn{2}{|c|}{ Total Weight } & 4215 & & & & 4035 & & & & \\
\hline
\end{tabular}




\begin{tabular}{|c|c|c|c|c|c|c|c|c|c|c|}
\hline \multicolumn{11}{|c|}{ Fa ( Abu batu ) } \\
\hline \multirow{2}{*}{\multicolumn{2}{|c|}{ Sieve Size }} & \multicolumn{4}{|c|}{ Sample 1} & \multicolumn{4}{|c|}{ Sample 2} & \multirow{3}{*}{$\begin{array}{c}\text { Averag } \\
\text { e } \\
\text { Passin } \\
\text { g } \\
(\%)\end{array}$} \\
\hline & & \multirow{2}{*}{$\begin{array}{l}\text { Individ } \\
\text { ual Wt } \\
\text { Retain } \\
\text { ed (Gr) }\end{array}$} & \multicolumn{3}{|c|}{ Weight Cumulative } & \multirow{2}{*}{$\begin{array}{l}\text { Individ } \\
\text { ual Wt } \\
\text { Retain } \\
\text { ed (Gr) }\end{array}$} & \multicolumn{3}{|c|}{ Weight Cumulative } & \\
\hline Inch & $\mathrm{mm}$ & & $\begin{array}{c}\text { Retain } \\
\text { ed } \\
(\mathrm{Gr}) \\
\end{array}$ & $\begin{array}{c}\text { Retain } \\
\text { d (\%) }\end{array}$ & $\begin{array}{c}\text { Passin } \\
\text { g (\%) }\end{array}$ & & $\begin{array}{c}\text { Retai } \\
\text { ned } \\
(\mathrm{Gr}) \\
\end{array}$ & $\begin{array}{c}\text { Retain } \\
\text { d (\%) }\end{array}$ & $\begin{array}{c}\text { Passin } \\
\mathrm{g}(\%)\end{array}$ & \\
\hline $3 / 4$ & 19,1 & & & & & & & & & \\
\hline $1 / 2$ & 12,7 & & & & & & & & & \\
\hline $3 / 8$ & 9,5 & & & & 100,00 & & & & 100,00 & 100,00 \\
\hline No. 4 & 4,76 & & 106,5 & 5,67 & 94,33 & & 67,2 & 4,33 & 95,67 & 95,00 \\
\hline No. 8 & 2,88 & & 517,6 & 27,56 & 72,44 & & 410,5 & 26,44 & 73,56 & 73,00 \\
\hline No. 16 & 1,19 & & 867,5 & 46,19 & 53,81 & & 729,6 & 47,00 & 53,00 & 53,41 \\
\hline No. 30 & 0,595 & & $\begin{array}{c}1067 \\
2\end{array}$ & 56,82 & 43,18 & & 853,2 & 54,96 & 45,04 & 44,11 \\
\hline No. 50 & 0,297 & & $\begin{array}{c}1219 \\
1\end{array}$ & 64,91 & 35,09 & & $\begin{array}{c}1064, \\
6\end{array}$ & 68,58 & 31,42 & 33,26 \\
\hline No. 100 & 0,150 & & $\begin{array}{c}1515 \\
7\end{array}$ & 80,70 & 19,30 & & $\begin{array}{c}1195, \\
2\end{array}$ & 76,99 & 23,01 & 21,16 \\
\hline No. 200 & 0,074 & & $\begin{array}{c}1709 \\
9\end{array}$ & 91,04 & 8,96 & & $\begin{array}{c}1412 \\
1\end{array}$ & 90,96 & 9,04 & 9,00 \\
\hline & & 1878,2 & & & & 1552,4 & & & & \\
\hline \multicolumn{2}{|c|}{ Cangkang Kerang } & & & & & & & & & \\
\hline \multirow{2}{*}{\multicolumn{2}{|c|}{ Sieve Size }} & \multicolumn{4}{|c|}{ Sample 1} & \multicolumn{4}{|c|}{ Sample 2} & \multirow{3}{*}{$\begin{array}{c}\text { Averag } \\
\text { e } \\
\text { Passin } \\
\text { g } \\
\text { (\%) }\end{array}$} \\
\hline & & $\begin{array}{l}\text { Individ } \\
\text { ual Wt }\end{array}$ & \multicolumn{3}{|c|}{ Weight Cumulative } & $\begin{array}{c}\text { Individ } \\
\text { ual Wt }\end{array}$ & \multicolumn{3}{|c|}{ Weight Cumulative } & \\
\hline Inch & $\mathrm{mm}$ & $\begin{array}{l}\text { Retain } \\
\text { ed (Gr) }\end{array}$ & $\begin{array}{c}\text { Retain } \\
\text { ed } \\
(\mathrm{Gr}) \\
\end{array}$ & $\begin{array}{c}\text { Retain } \\
\mathrm{d}(\%)\end{array}$ & $\begin{array}{c}\text { Passin } \\
\mathrm{g}(\%)\end{array}$ & $\begin{array}{l}\text { Retain } \\
\text { ed (Gr) }\end{array}$ & $\begin{array}{c}\text { Retai } \\
\text { ned } \\
(\mathrm{Gr}) \\
\end{array}$ & $\begin{array}{l}\text { Retain } \\
\mathrm{d}(\%)\end{array}$ & $\begin{array}{c}\text { Passin } \\
\mathrm{g}(\%)\end{array}$ & \\
\hline $3 / 4$ & 19,1 & & & & & & & & & \\
\hline $1 / 2$ & 12,7 & & & & & & & & & \\
\hline $3 / 8$ & 9,5 & & & & & & & & & \\
\hline No. 4 & 4,76 & & & & & & & & & \\
\hline No. 8 & 2,88 & & & & & & & & & \\
\hline No. 16 & 1,19 & & & & 100,00 & & & & 100,00 & 100,00 \\
\hline No. 30 & 0,595 & & 201,7 & 27,46 & 72,54 & & 202,8 & 25,80 & 74,20 & 73,37 \\
\hline No. 50 & 0,297 & & 385,3 & 52,45 & 47,55 & & 399,8 & 50,87 & 49,13 & 48,34 \\
\hline No. 100 & 0,150 & & 536,5 & 73,03 & 26,97 & & 557,8 & 70,97 & 29,03 & 28,00 \\
\hline No. 200 & 0,074 & & 603,3 & 82,12 & 17,88 & & 628,3 & 79,94 & 20,06 & 18,97 \\
\hline \multicolumn{2}{|c|}{ Total Weight } & 734,6 & & & & 786,0 & & & & \\
\hline
\end{tabular}

\section{Sumber: Hasil Laboratorium}

Data diatas adalah pada proses perhitungan dalam mencari prosentase masingmasing fraksi agregat campuran aspal murni dilakukan secara tersendiri. Hal tersebut dikarenakan masing-masing jenis agregat yang didapat mempunyai hasil yang berbeda pada masing-masing ukuran saringan. Untuk proses perhitungan itu sendiri menggunakan rumus dasar analitis penyesuaian proporsi agregat campuran. 
Sari, K., I. (2021). Pengaruh Serbuk Abu Cangkang Kerang Sebagai Bahan Pengganti Filler Pada Campuran Aspal.

Tabel 4.7. Hasil Perhitungan Penyesuaian Proporsi Agregat Campuran Normal

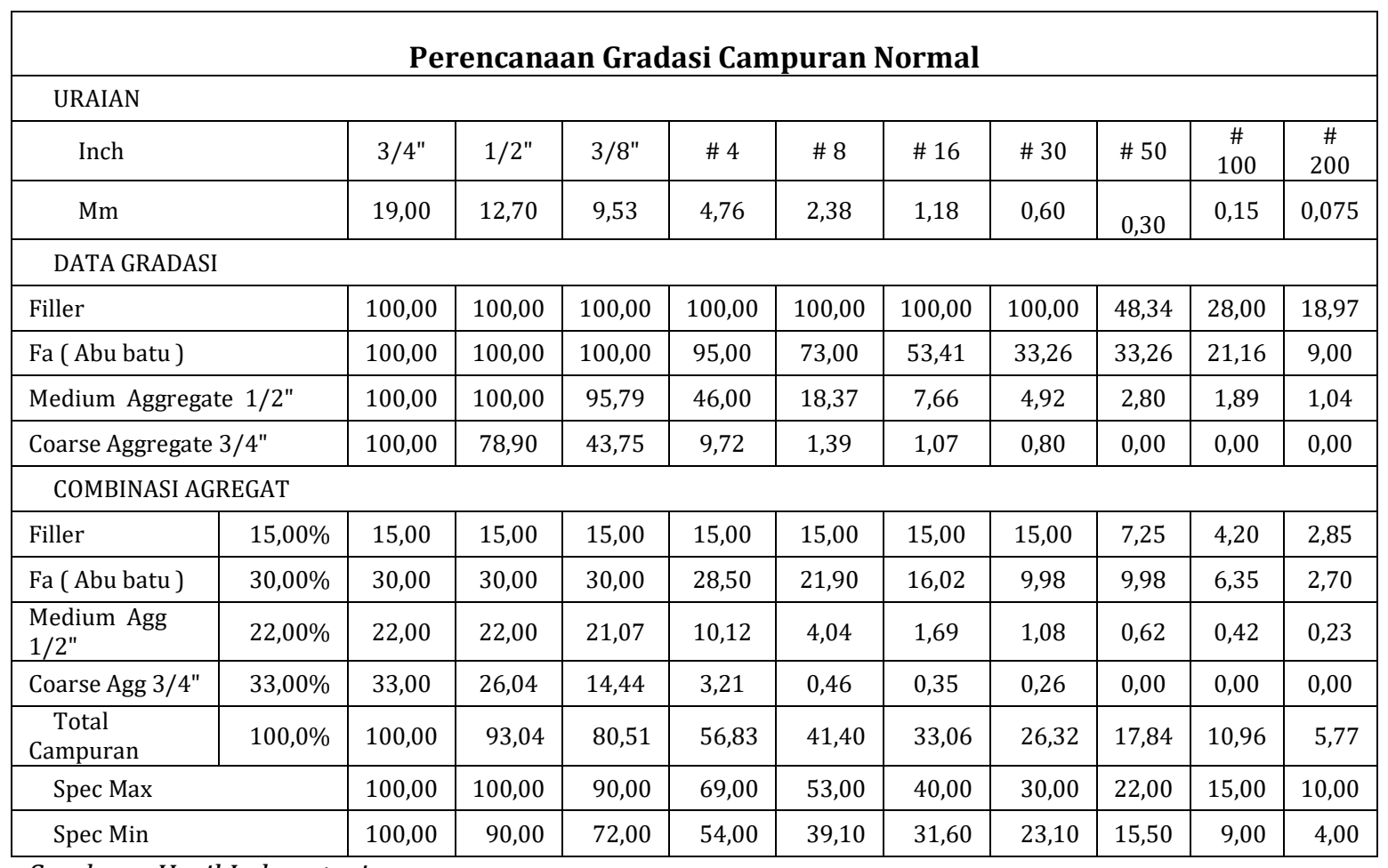

Sumber : Hasil Laboratorium

Pada Tabel 4.7. di atas terlihat prosentase

lolos masing-masing saringan mempunyai nilai yang berbeda. pada nilai masing-masing prosentase lolos saringan masih kami butuhkan dalam target rencana campuran untuk memudahkan dalam proses penimbangan yang mana alat penimbangan tersebut hanya mempunyai angka ketelitian 0,1 gram saja. Hasil dari marshal test yang mengacu pada Spesifikasi campuran Asphalt Concrete Wearing Course (ACWC mengacu pada Spesifikasi Kementrian Pekerjaan Umum Direktorat Jendral Bina Marga 2010 revisi 1 (BM 2010) menunjukan hasil bahwasanya telah memenuhi syarat yang ditentukan.

Tabel. 4.9 Gradasi Rencana Campuran $15 \%$

\begin{tabular}{|c|c|c|c|c|c|c|c|c|c|c|}
\hline \multicolumn{11}{|c|}{ Cangkang Kerang Sebagai Pengganti Filler 15 \% } \\
\hline & & & \multicolumn{5}{|c|}{ Sieve Analysis Test } & & & \\
\hline \multicolumn{2}{|c|}{$\begin{array}{c}\text { Coarse Agg } \\
3 / 4 " \\
\end{array}$} & & & & & & & & & \\
\hline \multirow{2}{*}{\multicolumn{2}{|c|}{ Sieve Size }} & \multicolumn{4}{|c|}{ Sample 1} & \multicolumn{4}{|c|}{ Sample 2} & $\begin{array}{c}\text { Averag } \\
\text { e }\end{array}$ \\
\hline & & \multirow{2}{*}{$\begin{array}{c}\text { Individua } \\
\text { l Wt } \\
\text { Retained } \\
\text { (Gr) } \\
\end{array}$} & \multicolumn{3}{|c|}{ Weight Cumulative } & \multirow{2}{*}{$\begin{array}{c}\text { Individua } \\
\text { l Wt } \\
\text { Retained } \\
\text { (Gr) }\end{array}$} & \multicolumn{3}{|c|}{ Weight Cumulative } & Passing \\
\hline Inch & $\mathrm{Mm}$ & & $\begin{array}{l}\text { Retaine } \\
\mathrm{d}(\mathrm{Gr})\end{array}$ & $\begin{array}{c}\text { Retain } \\
\mathrm{d}(\%)\end{array}$ & $\begin{array}{c}\text { Passin } \\
\mathrm{g}(\%) \\
\end{array}$ & & $\begin{array}{c}\text { Retaine } \\
\mathrm{d}(\mathrm{Gr})\end{array}$ & $\begin{array}{c}\text { Retaind } \\
(\%) \\
\end{array}$ & $\begin{array}{c}\text { Passin } \\
\mathrm{g}(\%) \\
\end{array}$ & $(\%)$ \\
\hline $3 / 4$ & 19,1 & & & & 100,00 & & & & 100,00 & 100,00 \\
\hline $1 / 2$ & 12,7 & 1591 & 1591 & 21,44 & 78,56 & & 1451 & 20,77 & 79,23 & 78,90 \\
\hline $3 / 8$ & 9,5 & 2680 & 4271 & 57,57 & 42,43 & & 3837 & 54,93 & 45,07 & 43,75 \\
\hline No. 4 & 4,76 & 2430 & 6702 & 90,33 & 9,67 & & 6303 & 90,23 & 9,77 & 9,72 \\
\hline No. 8 & 2,88 & 619 & 7321 & 98,68 & 1,32 & & 6883 & 98,54 & 1,46 & 1,39 \\
\hline
\end{tabular}




\begin{tabular}{|c|c|c|c|c|c|c|c|c|c|c|}
\hline No. 16 & 1,19 & 21 & 7342 & 98,96 & 1,04 & & 6909 & 98,91 & 1,09 & 1,07 \\
\hline No. 30 & 0,595 & 23 & 7365 & 99,27 & 0,73 & & 6925 & 99,14 & 0,86 & 0,80 \\
\hline No. 50 & 0,297 & & & & & & & & & \\
\hline \multicolumn{2}{|c|}{ Total Weight } & 7419 & & & & 6985 & & & & \\
\hline
\end{tabular}

\begin{tabular}{|c|c|c|c|c|c|c|c|c|c|c|}
\hline \multicolumn{2}{|c|}{$\begin{array}{c}\text { Medium Agg } \\
1 / 2 "\end{array}$} & & & & & & & & & \\
\hline \multirow{2}{*}{\multicolumn{2}{|c|}{ Sieve Size }} & \multicolumn{4}{|c|}{ Sample 1} & \multicolumn{4}{|c|}{ Sample 2} & \multirow{3}{*}{$\begin{array}{c}\text { Averag } \\
\mathrm{e} \\
\text { Passing } \\
(\%) \\
\end{array}$} \\
\hline & & \multirow{2}{*}{\begin{tabular}{|c|} 
Individual W \\
Retained \\
$(\mathrm{Gr})$
\end{tabular}} & \multicolumn{3}{|c|}{ Weight Cumulative } & \multirow{2}{*}{$\begin{array}{c}\text { ndividual } \mathrm{Wt} \\
\text { Retained } \\
(\mathrm{Gr})\end{array}$} & \multicolumn{3}{|c|}{ Weight Cumulative } & \\
\hline Inch & $\mathrm{Mm}$ & & $\begin{array}{c}\text { Retaine } \\
\mathrm{d}(\mathrm{Gr})\end{array}$ & $\begin{array}{c}\text { Retain } \\
\mathrm{d}(\%) \\
\end{array}$ & $\begin{array}{c}\text { Passin } \\
\mathrm{g}(\%) \\
\end{array}$ & & $\begin{array}{c}\text { Retaine } \\
\mathrm{d}(\mathrm{Gr})\end{array}$ & $\begin{array}{c}\text { Retaind } \\
(\%) \\
\end{array}$ & $\begin{array}{c}\text { Passin } \\
\mathrm{g}(\%)\end{array}$ & \\
\hline $3 / 4$ & 19,1 & & & & & & & & & \\
\hline $1 / 2$ & 12,7 & & & & 100,00 & & & & 100,00 & 100,00 \\
\hline $3 / 8$ & 9,5 & & 238 & 5,65 & 94,35 & & 112 & 2,78 & 97,22 & 95,79 \\
\hline No. 4 & 4,76 & & 2234 & 53,00 & 47,00 & & 2219 & 55,00 & 45,00 & 46,00 \\
\hline No. 8 & 2,88 & & 3459 & 82,06 & 17,94 & & 3276 & 81,20 & 18,80 & 18,37 \\
\hline No. 16 & 1,19 & & 3901 & 92,54 & 7,46 & & 3718 & 92,14 & 7,86 & 7,66 \\
\hline No. 30 & 0,595 & & 4015 & 95,25 & 4,75 & & 3830 & 94,91 & 5,09 & 4,92 \\
\hline No. 50 & 0,297 & & 4100 & 97,28 & 2,72 & & 3919 & 97,12 & 2,88 & 2,80 \\
\hline $\begin{array}{l}\text { No. } \\
100\end{array}$ & 0,150 & & 4141 & 98,24 & 1,76 & & 3953 & 97,98 & 2,02 & 1,89 \\
\hline $\begin{array}{l}\text { No. } \\
200\end{array}$ & 0,074 & & 4175 & 99,06 & 0,94 & & 3989 & 98,86 & 1,14 & 1,04 \\
\hline \multirow{2}{*}{\multicolumn{2}{|c|}{$\begin{array}{c}\text { Total Weight } \\
\text { Fa ( Abu batu } \\
\text { ) }\end{array}$}} & 4215 & & & & 4035 & & & & \\
\hline & & & & & & & & & & \\
\hline \multirow{2}{*}{\multicolumn{2}{|c|}{ Sieve Size }} & \multicolumn{4}{|c|}{ Sample 1} & \multicolumn{4}{|c|}{ Sample 2} & \multirow{3}{*}{$\begin{array}{c}\text { Averag } \\
\text { e } \\
\text { Passing } \\
(\%)\end{array}$} \\
\hline & & \multirow{2}{*}{\begin{tabular}{|c|} 
ndividual W \\
Retained \\
$(\mathrm{Gr})$
\end{tabular}} & \multicolumn{3}{|c|}{ Weight Cumulative } & Idividual Wt & \multicolumn{3}{|c|}{ Weight Cumulative } & \\
\hline Inch & $\mathrm{Mm}$ & & $\begin{array}{c}\text { Retaine } \\
\mathrm{d}(\mathrm{Gr})\end{array}$ & $\begin{array}{c}\text { Retain } \\
\mathrm{d}(\%) \\
\end{array}$ & $\begin{array}{c}\text { Passin } \\
\mathrm{g}(\%) \\
\end{array}$ & $\begin{array}{l}\text { Retained } \\
\text { (Gr) }\end{array}$ & $\begin{array}{l}\text { Retaine } \\
\mathrm{d}(\mathrm{Gr})\end{array}$ & $\begin{array}{c}\text { Retaind } \\
(\%)\end{array}$ & $\begin{array}{c}\text { Passin } \\
\mathrm{g}(\%) \\
\end{array}$ & \\
\hline $3 / 4$ & 19,1 & & & & & & & & & \\
\hline $1 / 2$ & 12,7 & & & & & & & & & \\
\hline $3 / 8$ & 9,5 & & & & 100,00 & & & & 100,00 & 100,00 \\
\hline No. 4 & 4,76 & & 106,5 & 5,67 & 94,33 & & 67,2 & 4,33 & 95,67 & 95,00 \\
\hline No. 8 & 2,88 & & 517,6 & 27,56 & 72,44 & & 410,5 & 26,44 & 73,56 & 73,00 \\
\hline No. 16 & 1,19 & & 858,5 & 45,71 & 54,29 & & 680,1 & 43,81 & 56,19 & 55,24 \\
\hline No. 30 & 0,595 & & 1067,2 & 56,82 & 43,18 & & 853,2 & 54,96 & 45,04 & 44,11 \\
\hline No. 50 & 0,297 & & 1235,1 & 65,76 & 34,24 & & 1085,0 & 69,89 & 30,11 & 32,18 \\
\hline $\begin{array}{l}\text { No. } \\
100\end{array}$ & 0,150 & & 1515,7 & 80,70 & 19,30 & & 1195,2 & 76,99 & 23,01 & 21,16 \\
\hline $\begin{array}{l}\text { No. } \\
200\end{array}$ & 0,074 & & 1709,9 & 91,04 & 8,96 & & 1412,1 & 90,96 & 9,04 & 9,00 \\
\hline & & 1878,2 & & & & 1552,4 & & & & \\
\hline \multicolumn{11}{|c|}{$\begin{array}{l}\text { Cangkang } \\
\text { Kerang }\end{array}$} \\
\hline \multirow{2}{*}{\multicolumn{2}{|c|}{ Sieve Size }} & \multicolumn{4}{|c|}{ Sample 1} & \multicolumn{4}{|c|}{ Sample 2} & \multirow{3}{*}{$\begin{array}{c}\text { Averag } \\
\text { e } \\
\text { Passing } \\
(\%)\end{array}$} \\
\hline & & \multirow{2}{*}{\begin{tabular}{|c} 
ndividual W \\
Retained \\
$(\mathrm{Gr})$ \\
\end{tabular}} & Wei & it Cumul & & ndividual $\mathrm{Wt}$ & $\mathrm{We}$ & ht Cumula & ive & \\
\hline Inch & $\mathrm{Mm}$ & & $\begin{array}{c}\text { Retaine } \\
\mathrm{d}(\mathrm{Gr}) \\
\end{array}$ & $\begin{array}{c}\text { Retain } \\
\mathrm{d}(\%) \\
\end{array}$ & $\begin{array}{c}\text { Passin } \\
\mathrm{g}(\%) \\
\end{array}$ & $\begin{array}{c}\text { Retained } \\
\text { (Gr) }\end{array}$ & $\begin{array}{c}\text { Retaine } \\
\mathrm{d}(\mathrm{Gr}) \\
\end{array}$ & $\begin{array}{c}\text { Retaind } \\
(\%) \\
\end{array}$ & $\begin{array}{c}\text { Passin } \\
\mathrm{g}(\%) \\
\end{array}$ & \\
\hline $3 / 4$ & 19,1 & & & & & & & & & \\
\hline $1 / 2$ & 12,7 & & & & & & & & & \\
\hline $3 / 8$ & 9,5 & & & & & & & & & \\
\hline No. 4 & 4,76 & & & & & & & & & \\
\hline No. 8 & 2,88 & & & & & & & & & \\
\hline No. 16 & 1,19 & & & & 100,00 & & & & 100,00 & 100,00 \\
\hline No. 30 & 0,595 & & 201,7 & 27,46 & 72,54 & & 202,8 & 25,80 & 74,20 & 73,37 \\
\hline No. 50 & 0,297 & & 385,3 & 52,45 & 47,55 & & 399,8 & 50,87 & 49,13 & 48,34 \\
\hline
\end{tabular}


Sari, K., I. (2021). Pengaruh Serbuk Abu Cangkang Kerang Sebagai Bahan Pengganti Filler Pada Campuran Aspal.

\begin{tabular}{|l|l|l|l|l|l|l|l|l|l|c|}
\hline $\begin{array}{l}\text { No. } \\
100\end{array}$ & 0,150 & & 536,5 & 73,03 & 26,97 & & 557,8 & 70,97 & 29,03 & 28,00 \\
\hline $\begin{array}{l}\text { No. } \\
200\end{array}$ & 0,074 & & 603,3 & 82,12 & 17,88 & & 628,3 & 79,94 & 20,06 & 18,97 \\
\hline \multicolumn{2}{|l|}{ Total Weight } & 734,6 & & & & 786,0 & & & & \\
\hline
\end{tabular}

Sumber : Hasil Laboratorium

Data diatas adalah pada proses masing fraksi agregat campuran filler kerang darah perhitungan dalam mencari prosentase masing- $\quad$ sebesar $15 \%$ dilakukan secara tersendiri.

Tabel 4.10. Hasil Analisa Marshall Pada Kadar Aspal Rencana Untuk Sample Murni

\begin{tabular}{|c|c|c|c|c|c|c|c|c|c|c|c|c|c|c|}
\hline \multirow{4}{*}{$\begin{array}{c}\text { SPE } \\
\text { C } \\
\text { NO }\end{array}$} & \multirow[b]{2}{*}{$\begin{array}{c}\text { BITUM } \\
\text { ENT } \\
\text { CONTE } \\
\text { NT }\end{array}$} & \multirow[b]{2}{*}{$\begin{array}{c}\text { BULK } \\
\text { SpGR of } \\
\text { TOTAL } \\
\text { AGG }\end{array}$} & \multirow[b]{2}{*}{$\begin{array}{c}\text { EFF SpGr } \\
\text { F TOTAL } \\
\text { AGG }\end{array}$} & & \multirow[b]{2}{*}{$\begin{array}{l}\text { VOLU } \\
\text { ME OF } \\
\text { SPECI } \\
\text { MEN }\end{array}$} & \multirow[b]{2}{*}{$\begin{array}{c}\text { BULK } \\
\text { DENSI } \\
\text { TY }\end{array}$} & \multirow[b]{2}{*}{$\begin{array}{l}\text { AIR VOID } \\
\text { (VIM) }\end{array}$} & \multirow[b]{2}{*}{$\begin{array}{c}\text { VMA } \\
\%\end{array}$} & \multirow[b]{2}{*}{$\begin{array}{c}\% \text { VOIDS } \\
\text { FILLED } \\
\text { (VFA) }\end{array}$} & \multicolumn{3}{|c|}{ STABILITY } & \multirow[b]{2}{*}{$\begin{array}{l}\text { FLO } \\
\text { W } \\
\text { MM }\end{array}$} & \multirow{2}{*}{$\begin{array}{c}\text { MARSH } \\
\text { ALL } \\
\text { QUOTIE } \\
\text { NT } \\
(\mathrm{Kg} / \mathrm{m} \\
\mathrm{m})\end{array}$} \\
\hline & & & & $\begin{array}{c}\text { MAX SpGr } \\
\text { COMBAIN } \\
\text { ED MIX }\end{array}$ & & & & & & $\begin{array}{c}\text { MEA } \\
\mathrm{S}\end{array}$ & $\begin{array}{c}\text { ADJU } \\
\text { ST } \\
\text { Kg }\end{array}$ & $\begin{array}{c}\text { ADJU } \\
\text { ST } \\
\mathrm{Kg}\end{array}$ & & \\
\hline & $\mathrm{A}$ & $\mathrm{B}$ & $\mathrm{C}$ & $\mathrm{D}$ & $\mathrm{H}$ & I & $\mathrm{N}$ & 0 & $\mathrm{P}$ & $Q$ & $\mathrm{R}$ & $\mathrm{S}$ & $\mathrm{T}$ & $\mathrm{U}$ \\
\hline & $\begin{array}{c}\% \text { BIT } \\
\text {.BY } \\
\text { WT.OF } \\
\text { MIX }\end{array}$ & $\begin{array}{l}\text { REFER } \\
\text { NOTE } 1 \\
\text { BELOW }\end{array}$ & $\begin{array}{l}\text { REFER } \\
\text { NOTE } 2 \\
\text { BELOW }\end{array}$ & $\begin{array}{c}100 \\
\frac{100-A}{C} \\
+\frac{A}{X}\end{array}$ & $\begin{array}{l}\text { FROM } \\
\text { LAB }\end{array}$ & G-F & $\frac{100 \times(D-}{D}$ & $\mathrm{~L}+\mathrm{N}$ & $\frac{L X 100)}{O}$ & $\begin{array}{l}\text { FRO } \\
\text { M } \\
\text { LAB }\end{array}$ & $\begin{array}{c}\text { FRO } \\
\text { M } \\
\text { LAB }\end{array}$ & $\begin{array}{l}\text { FRO } \\
\text { M } \\
\text { LAB }\end{array}$ & $\begin{array}{c}\text { FRO } \\
\text { M } \\
\text { LAB }\end{array}$ & $\frac{S}{T}$ \\
\hline \multirow[t]{4}{*}{1} & $5,00 \%$ & 2,573 & 2,604 & 2,417 & 518,4 & 2,267 & 6,21 & $\begin{array}{c}16,2 \\
3\end{array}$ & 61,76 & 69 & 1035 & 993 & 2,75 & 361 \\
\hline & & & & & 528,8 & 2,266 & 6,25 & $\begin{array}{c}16,2 \\
7\end{array}$ & 61,59 & 66 & 990 & 950 & 2,70 & 352 \\
\hline & & & & & 528,0 & 2,273 & 5,96 & $\begin{array}{c}16,0 \\
1\end{array}$ & 62,78 & 72 & 1080 & 1036 & 2,80 & 370 \\
\hline & & & & & & 2,269 & 6,14 & $\begin{array}{c}16,1 \\
7\end{array}$ & 62,04 & & & 993 & 2,75 & 361 \\
\hline \multirow[t]{4}{*}{2} & $5,50 \%$ & 2,573 & 2,604 & 2,400 & 512,8 & 2,279 & 5,04 & $\begin{array}{c}16,2 \\
4\end{array}$ & 68,95 & 76 & 1140 & 1094 & 3,15 & 347 \\
\hline & & & & & 515,7 & 2,275 & 5,21 & $\begin{array}{c}16,3 \\
8\end{array}$ & 68,21 & 80 & 1200 & 1152 & 3,45 & 334 \\
\hline & & & & & 512,8 & 2,281 & 4,96 & $\begin{array}{c}16,1 \\
6\end{array}$ & 69,32 & 85 & 1274 & 1224 & 3,30 & 371 \\
\hline & & & & & & 2,278 & 5,07 & $\begin{array}{c}16,2 \\
6\end{array}$ & 68,83 & & & 1156 & 3,30 & 351 \\
\hline \multirow[t]{4}{*}{3} & $6,00 \%$ & 2,573 & 2,604 & 2,383 & 507,5 & 2,296 & 3,65 & $\begin{array}{c}16,0 \\
6\end{array}$ & 77,26 & 94 & 1409 & 1466 & 3,60 & 407 \\
\hline & & & & & 523,5 & 2,289 & 3,94 & $\begin{array}{c}16,3 \\
1\end{array}$ & 75,82 & 88 & 1319 & 1267 & 3,55 & 357 \\
\hline & & & & & 521,9 & 2,297 & 3,61 & $\begin{array}{c}16,0 \\
2\end{array}$ & 77,47 & 96 & 1439 & 1439 & 3,45 & 417 \\
\hline & & & & & & 2,294 & 3,73 & $\begin{array}{c}16,1 \\
3\end{array}$ & 76,85 & & & 1391 & 3,53 & 394 \\
\hline \multirow[t]{4}{*}{4} & $6,50 \%$ & 2,573 & 2,604 & 2,366 & 524,6 & 2,288 & 3,30 & $\begin{array}{c}16,7 \\
8 \\
\end{array}$ & 80,36 & 84 & 1259 & 1209 & 4,70 & 257 \\
\hline & & & & & 523,8 & 2,289 & 3,25 & $\begin{array}{c}17,7 \\
9 \\
\end{array}$ & 81,71 & 82 & 1230 & 1180 & 4,45 & 265 \\
\hline & & & & & 520,4 & 2,286 & 3,38 & $\begin{array}{c}17,9 \\
0\end{array}$ & 81,11 & 87 & 1304 & 1304 & 3,75 & 348 \\
\hline & & & & & & 2,288 & 3,31 & $\begin{array}{c}17,4 \\
9 \\
\end{array}$ & 81,06 & & & 1231 & 4,30 & 290 \\
\hline \multirow[t]{4}{*}{5} & $7,00 \%$ & 2,573 & 2,604 & 2,350 & 528,9 & 2,266 & 3,57 & $\begin{array}{c}18,0 \\
4\end{array}$ & 80,19 & 72 & 1080 & 1036 & 4,55 & 228 \\
\hline & & & & & 525,6 & 2,268 & 3,49 & $\begin{array}{c}17,9 \\
7\end{array}$ & 80,58 & 75 & 1125 & 1080 & 4,60 & 235 \\
\hline & & & & & 522,8 & 2,272 & 3,32 & $\begin{array}{c}17,8 \\
3 \\
\end{array}$ & 81,38 & 79 & 1185 & 1185 & 4,50 & 263 \\
\hline & & & & & & 2,269 & 3,46 & $\begin{array}{c}17,9 \\
5\end{array}$ & 80,72 & & & 1100 & 4,55 & 242 \\
\hline
\end{tabular}

Sumber : Hasil Laboratorium 
Pengujian dengan alat Marshall dilakukan sesuai dengan prosedur untuk mengetahui karakteristik campuran, menentukan ketahanan atau stabilitas terhadap kelelehan plastis (flow) dari campuran aspal murni.Dari hasil pengujian marshall test di diatas yang telah di tuangkan dalam grafik dan tabel dapat di simpulkan bahwa campuran gradasi agregat yang digunakan untuk campuran asphalt murni sudah memenuhi standar dalam pemilian agregat untuk asphalt menurut spesifikasi bina marga.

Dengan demikian pada pengujian Marshall kemudian didapat hubungan antara presentase kadar aspal dengan presentase rongga terisi aspal (VFA) 80,60\%, presentase rongga dalam campuran (VIM) 3,10\%, kelelehan (flow) 4,20\%, stabilitas $1245 \mathrm{Kg}$, Keuatan (MQ) 300,00\%. Dengan demikian campuran agregat aspal tetrsebut dapat digunakan untuk pengaplikasian pada jalan dengan beban menengah.

\section{SIMPULAN}

\section{Kesimpulan}

Dari hasil penelitian pengaruh penggantian sebagian filler cangkang kerang sebesar $15 \%$ dan $25 \%$.

1. Hasil dari penelitian yang di lakukan menunjukan bahwa pengujian menunjukan perubahan nilai stabiltas, densitas, VIM, VMA, dan MQ secara nyata.

2. Hasil dari karakteristik Marshall test filler cangkang kerang pada kadar 15\% dan $25 \%$ untuk campuran asphalt AC-WC 60/70 untuk nila stabilitas, densitas, VIM, VA dan MQ telah memenuhi standar spesifikasi Kementrian Pekerjaan Umum Direktorat Jendral Bina Marga 2010 revisi 1 (BM 2010).

3. Penambahan filler cangkang kerang pada pada campuran asphalt menghasilkan nilai stabilitas untuk campuran 15\% sebesar 1192 Kg dan 25\% sebesar 1245 $\mathrm{Kg}$.

4. Penambahan filler cangkang kerang pada pada campuran asphalt menghasilkan nilai VIM untuk campuran 15\% sebesar $3,35 \%$ dan $25 \%$ sebesar 3,10\%.

5. Penambahan filler cangkang kerang pada pada campuran asphalt menghasilkan nilai VMA untuk campuran 15\% sebesar $16,25 \mathrm{Kg} / \mathrm{mm}$ dan $25 \%$ sebesar 16,10 $\mathrm{Kg} / \mathrm{mm}$.

6. Penambahan filler cangkang kerang pada pada campuran asphalt menghasilkan nilai VFA untuk campuran 15\% sebesar $16,25 \mathrm{Kg} / \mathrm{mm}$ dan $25 \%$ sebesar 16,10 $\mathrm{Kg} / \mathrm{mm}$.

7. Penambahan filler cangkang kerang pada pada campuran asphalt menghasilkan nilai MQ untuk campuran 15\% sebesar $305,00 \%$ dan $25 \%$ sebesar $300 \%$.

8. Penambahan filler cangkang kerang pada pada campuran asphalt menghasilkan nilai MQ untuk campuran 15\% sebesar $3,95 \%$ dan $25 \%$ sebesar $4,20 \%$.

\section{DAFTAR PUSTAKA}

Afif Teuku Muhammad, (2012). Kajian Karakteeristik Campuran Aspal Beton Lapis Aus $(A C-W C)$ Menurut Spesifikasi Umum Bina Marga Edisi 2006 dan 2010, Medan: Departemen Teknik Sipil Universitas Sumetera Utara.

Anonim, (1976), Departemen Pekerjaan Umum dan Tenaga Listrik, Manual Pemeriksaan Bahan Jalan, Direktorat Jendral Bina Marga, No.01/MN/BM/ 1976, Jakarta. 
Sari, K., I. (2021). Pengaruh Serbuk Abu Cangkang Kerang Sebagai Bahan Pengganti Filler Pada Campuran Aspal.

Anonim, (2010). Spesifikasi Umum Divisi VII, Kementrian Pekerjaan Umum Direktorat Jendral Bina Marga Republik Indonesia.

Putrowijoyo R, (2006). Kajian Laboratorium Sifat Marshall Dan Durabilitas Asphalt Concrete Wearing Course $(A c-W c)$ Dengan
Membandingkan Penggunaan Antara Semen Portland Dan Abu Batu Sebagai Filler. Semarang : Universitas Diponogoro

Simanjuntak, Zulkarrnain, Studi Pengaruh Penggunaan Filler Semen, Serbuk betonik, dan Abu Terbang Batubara terhadap Karakteristik Campura. 